1 Retrieved from https://cyberleninka.ru/article/v/osobennosti-horeograficheskoy-podgotovki-v-sinhronnom-plavaniina-nachalnom-etape-obucheniya [in Russian].

6. Mostovaja, T. (2017). Choreography in sports as a means of plastic expression. Scientific notes of Oryol State University, 1, 191-193 [in Russian].

7. Novikova, E. (1981). Analysis of synchronized swimming techniques. Moscow: GTSOLIFK [in Russian]. Ukrainian].

8. Ozerova, O. (2006). Method of raising the level of tactical training of skilled swimmers. Kyiv [in

9. Onoprienko, B. (1960). Figure swimming. Moscow: Physical Education and Sport [in Russian].

10. Parfenov, V. \& Kononenko, Ju. (1979). Synchronized swimming. Kyiv: Health [in Russian].

11. Platonov, V. (2004). The system of training athletes in the Olympic sport. General theory and its practical applications. Kyiv: Olympic literature [in Russian].

12. Plehanova, M. (2006). Features of performance in technical and aesthetic sports. Moscow [in Russian].

13. Saraf, M. \& Stoljarov, V. (1986). Introduction to the aesthetics of sport. Moscow: FiS [in Russian].

14. Shipilina, I. (2004). Choreography in sport. Rostov-on-Don: Phoenix [in Russian].

Стаття надійшла до редакиії 11.01.2019 p.

УДК 792.8

\author{
Хоцяновська Людмила Францівна, \\ доцент кафедри народної \\ та класичної хореографії \\ Київського національного університету \\ культури і мистецтв
}

\title{
КУРТ ЙОСС - ТЕОРЕТИК, ПРАКТИК, ПЕДАГОГ ТА ЙОГО ВПЛИВ НА РОЗВИТОК СУЧАСНОГО ХОРЕОГРАФІЧНОГО МИСТЕЦТВА
}

Головна мета дослідження розкриваються аспекти діяльності видатного хореографа ХХ століття Курта Йосса, його новації та здобутки, що мали вагомий вплив на розвиток сучасного хореографічного мистецтва. Методологія дослідження. У ході дослідження були використані наступні методи: порівняння, узагальнення, систематизація та інтерпретація фактів. Науковою новизною для українського мистецтвознавства $\epsilon$ дослідження впливу різнобічної діяльності Курта Йосса на становлення та розвиток європейського сучасного танцю, що досі не ставало об'єктом окремого дослідження. У статті аналізуються здобутки К. Йосса у розробці теоретичних засад та методики викладання модерн-танцю які дали змогу не тільки покращити якість професійної освіти у сфері сучасної хореографії, а ще й значно розширити лексичний потенціал модерн-танцю. Розглянуто внесок митця у розвиток теоретичних питань мистецтва, а саме 3'ясування категорій «абсолютний танець», «театральний танець» і «танцювальний театр». Окреслено новаторство Йосса як балетмейстера у розширенні балетної тематики та художніх засобів сучасного танцю на прикладі балету «Зелений стіл», проаналізовано його ідейно-тематичну основу і творчий задум. Зазначено важливість розробки Куртом Йоссом системи «Еукінетика», та його співавторство у створенні «Кінетографії». Висновки. У статті доведено, що різнобічна діяльність Курта Йосса охопила різні сфери сучасної хореографії, справивши значний вплив на розвиток танцювального мистецтва багатьох країн Свропи та Світу. Конкретизовані напрями діяльності К. Йосса, за якими було здійснено значні новації та здобутки: а саме практичний, що реалізувався у заснуванні шкіл та викладацькій діяльність, вдосконалення техніки сучасного танцю, започаткування нового сценічного жанру «танцтеатр», розширення тематики балетного репертуару, значний постановчий доробок; методичний, що втілився в удосконаленні системи викладання модерн-танцю; новацією методологічного напряму стало запропонування методу творення хореографічної лексики засобом синтезу модерного та класичного танцю і не балетної пантоміми; теоретичний напрям надав обгрунтування та введення у науковий обіг терміну «танцтеатр», розробка системи «Еукінетика», співавторство у створенні «Кінетографії».

Ключові слова: сучасна хореографія, система викладання танцю модерн, театральний танець, танцтеатр.

Хоцяновская Людмила Францевна, доцент кафедры народной и класической хореографии Киевского национальный университет культуры и исскуств

Курт Йосси - теоретик, практик, педагог и его влияние на развитие современного хореографического искусства

Главная цель исследования аспекты деятельности выдающегося хореографа ХХ века Курта Йосса, его новации и достижения, имевшие значительное влияние на развитие современного хореографического искусства. Методология исследования. В ходе исследования были использованы следующие методы:

(C) Хоцяновська Л. Ф., 2019 
сравнение, обобщение, систематизация и интерпретация фактов. Научной новизной для украинского искусствоведения является исследование влияния разносторонней деятельности Курта Йосса на становление и развитие европейского современного танца, до сих пор не становилось объектом отдельного исследования. В статье анализируются достижения К. Йосса в разработке теоретических основ и методики преподавания модерн-танца которые позволили не только улучшить качество профессионального образования в сфере современной хореографии, но и значительно расширить лексический потенциал модерн-танца. Рассмотрены вклад художника в развитие теоретических вопросов искусства, а именно выяснения категорий «абсолютный танец», «театральный танец» и «танцевальный театр». Определены новаторство Йосса как балетмейстера в расширении балетной тематики и художественных средств современного танца на примере балета «Зеленый стол», проанализированы его идейно-тематическую основу и творческий замысел. Указано важность разработки Куртом Йосси системы «Еукинетика», и его соавторство в создании «Кинетографии». Выводы. В статье доказано, что разносторонняя деятельность Курта Йосса охватила различные сферы современной хореографии, произведя значительное влияние на развитие танцевального искусства многих стран Европы и Мира. Конкретизированы направления деятельности К. Йосса, по которым была осуществлена значительные новации и достижения: именно практический, что реализовался в создании школ и преподавательской деятельности, совершенствования техники современного танца, начало нового сценического жанра «Танцтеатра», расширение тематики балетного репертуара, значительный постановочный доработок ; методический, воплотившийся в совершенствовании системы преподавания модерн-танца; новацией методологического направления стало предлагаемых метода создания хореографической лексики средством синтеза современного и классического танца и не балетной пантомимы; теоретическое направление предоставил обоснование и введение в научный оборот термина «Танцтеатра», разработка системы «Еукинетика», соавторство в создании «Кинетографии».

Ключевые слова: современная хореография, система преподавания танца модерн, театральний танец, танцтеатр.

Khotsianovska Liudmyla, Associate Professor at the Department of the National and Classical Choreography Kyiv National University of Culture and Arts

Kurt Jooss - a theoretic, a practician, a pedagogue and his influence on the development of modern choreographic art

The purpose of the article - aspects of the work of an outstanding choreographer of the XXth century, Kurt Jooss, his innovations and achievements, which had a significant impact on the development of contemporary choreographic art. Methodology. In the course of the study, the following methods were used: comparison, generalization, systematization, and interpretation of facts. The scientific novelty for Ukrainian art studies is the study of the influence of Kurt Jooss's versatile activity on the formation and development of European contemporary dance, which has not yet become the subject of a separate study. The article analyzes the achievements of K. Jooss in elaborating theoretical principles and teaching methods of modern dance that allowed not only to improve the quality of professional education in the field of modern choreography but also to significantly expand the lexical potential of modern dance. The contribution of the artist to the development of theoretical issues of art is considered, namely the clarification of the categories "absolute dance", "theatrical dance" and "dance theater". The innovations of Jooss as a choreographer in the expansion of ballet subjects and artistic means of modern dance on the example of the ballet "The Green Table" are outlined, his ideological and thematic basis and creative idea analyzed. The importance of Kurt Jooss's development of the Eurythmics system is noted, as well as his co-authorship in the creation of "Kinetography". Conclusions. The article proves that Kurt Jooss's versatile activity encompassed various areas of modern choreography, having made a significant impact on the development of dance art in many countries of Europe and worldwide. The directions of K. Jooss's activities are specified, which made significant innovations and achievements, in particular, the practical implementation of the founding of schools and teaching activities, the improvement of modern dance techniques, the initiation of a new stage genre, "dance theater", the expansion of the subjects of ballet repertoire, significant staging achievements; methodological, embodied in the improvement of the system of teaching the modern dance; an innovation in the methodological direction was the proposal to create a choreographic vocabulary by means of the synthesis of modern and classical dance and non-ballet pantomime; the theoretical direction provided the substantiation and introduction into the scientific circle of the term "dance theater", the development of the system "Eurythmics", co-authorship in the creation of "Kinetography".

Key words: modern choreography, a system of teaching of dance modernist style, theater dance, dance theater.

Постановка проблеми. Сучасна сцена пред’являє особливі вимоги до танцівника, перша 3 них - універсальність. Більшість театрів в усьому світі мають у своєму репертуарі і балети класичної спадщини, і кращі зразки модерних балетів, неокласичні та постмодерні вистави, експериментальні твори сучасних балетмейстерів. Танцівник сьогодення, щоб бути затребуваним, має володіти як технікою класичного танцю, так і техніками танцю модерн, бути обізнаним у сучасних стилях хореографії та готовим до експериментів. Система виховання танцівника має поєднувати різні напрями хореографічного мистецтва. У вітчизняній педагогіці такий досвід є недостатнім сформовані поважні традиції викладання класичного та характерного танцю, а система викладання 
новітніх напрямів хореографії у вищій школі перебуває у стані становлення. Також, важко визначити оптимальну міру того та іншого. Тому особливо актуальним і корисним виступає дослідження досвіду видатних європейських діячів хореографічного мистецтва, серед яких знаний представник хореографічного експресіонізму, теоретик, педагог і балетмейстер Курт Йосс.

Аналіз останніх досліджень і публікацій. Літературні джерела європейського видання, присвячені розвитку сучасної хореографії XX ст., обов'язково містять змістовний розділ, присвячений творчості К. Йосса. [5; 6; 7; 8] Дослідники А.Ізрин, Дж.Хоманс, М.Марсель, І. Жіно вважають Йосса одним із фундаторів Ausdruktanz (виразного танцю). Обсяг інформації українською та російською мовами стосовно даної персоналії досить обмежений. Переважно ім'я Курта Йосса згадується лише мимохіть, як учня та соратника Рудольфа фон Лабана. (Д. Шариков) [3] Публікація А.Демідова присвячена аналізу певної роботи К.Йосса - балету «Зелений стіл».[1] Найбільш докладна інформація що до діяльності Йосса міститься у роботі О.Чепалова.[2] Автор розглядає ії у контексті становлення німецького театру танцю. Аналіз наукових джерел дає висновок, що вплив діяльності Курта Йосса на становлення та розвиток європейського сучасного танцю в українському мистецтвознавстві досі на став об’єктом окремого дослідження, що робить звернення до даної теми виправданим.

Метою статті є визначення впливу діяльності К. Йосса на становлення та розвиток модерного танцю у Європі. Мета зумовлює наступні завдання: дослідити доробок К. Йосса у царині хореографії; з'ясувати його значущість для розвитку європейського хореографічного мистецтва.

Результати дослідження. Французька дослідниця Агне Ізрін називає К. Йосса третім, після Рудольфа Фон Лабана та Мері Вігман, великим перетворювачем танцю у Німеччині. [5, 51] Як відомо, саме ця країна була ядром розвитку європейського сучасного танцю до початку Другої світової війни. Зважаючи на це, та беручи до уваги чисельні поїздки К. Йосса до інших країн Європи та Америки, можна говорити про вплив його діяльності на весь процес становлення модерного танцю у Європі, та навіть у світі.

Народився Курт Йосс 12 січня 1901 р. Професія матері-співачки спричинила захоплення Йосса музикою та театром і вступ до Штутгартської консерваторії. Та в 1920 р. він відкриває для себе танець познайомившись з роботою Рудольфа фон Лабана та відвідавши виступи Мері Вігман. К. Йосс приєднується до Р. фон Лабана (котрий керував на той час Національним Театром Мангейма) перших три роки у якості учня, а по тому, як соліст-танцівник i співавтор-хореограф. Їх експресіоністичні хореографічно-пантомімні вистави мали великий успіх у Німеччині. Митці відшукують нові танцювальні жести та рухи, використовують маски, велику увагу надають костюму та гриму.

1924 р. Йосс займає посаду балетмейстера у муніципальному театрі Мюнстера, на той час передовій залі, де цілі вечори присвячувались балету, і створює там чисельні постановки, серед яких сюрреалістична вистава без музичного супроводу «Сльози», експресіоністичні «Персидська казка» (муз. Велеса), «Демон» (муз. Хіндеміта) та ін.

3 метою удосконалення своєї професійної майстерності засобом вивчення класичного танцю К. Йосс прямує до Відня, Парижу, Ессена. Саме у Ессені Йосс згодом засновує «Folkwangschule» (школу сучасного танцю), а пізніше Студію театра танцю «Folkwangsbtihne». Здобувши визнання, діяч був призначений балетмейстером Опери Ессена, а його танцівники склали балетну трупу цього театру.

Уже $з$ 1920-х р. Курт Йосс звертає увагу на відсутність теоретичних засад та методики викладання модерн-танцю, який у більшій мірі спирається на індивідуальну обдарованість виконавця, ніж на систематизоване виховання танцівника. Вирішення цих проблем він бачить у зверненні до досвіду класичної хореографії. Створюючи свою систему викладання сучасного танцю, Йосс запозичує принципи побудови тренажу біля палки та велику кількість рухів академічної школи. М. Мішель та І. Жіно засвідчують, що техніка Йосса, розроблена впродовж 20 -х років являла собою суміш класичного танцю з принципами Лабана. [7, 100] Таке поєднання багатовікового досвіду 3 новаціями дало змогу не тільки покращити якість професійної освіти у сфері сучасної хореографії, а ще й значно розширити лексичний потенціал модерн-танцю.

Розробляючи теоретичні питання мистецтва, Курт Йосс звертається до актуальних художніх проблем, зокрема до з'ясування категорій «театральний танець» і «танцювальний театр». У промові, проголошеній на II Танцювальному конгресі в Ессені (1928р.), зазначив, що бурхливий розвиток танцю та інших сценічних мистецтв того часу спричинив відокремлення двох відмінних понять. А саме, «абсолютний танець» - танець сам у собі, побудований виключно на танцювальних законах композиції, у більшості випадків без драматичної, сюжетної дії. Інший прояв - «театральний танець», 
протилежна крайність, танець як засіб інших сценічних мистецтв - танець в опері, драматичній виставі, пантомімі. Тут на першому плані стоїть літературний зміст, дія, котру танець має донести якомога точніше.

Обидва вищезгаданих види танцю зв’язуються у третій категорії - «танцювальній драмі» - в чудесну єдність. Танцювально-драматичний шедевр, за Йоссом, виникає із одночасних танцювальних i драматичних імпульсів. I більше не можливо визначити, чи закони танцювальної форми, чи необхідність розгортання сюжету визначають структуру твору: хореографічна воля формує драму, котра, зі свого боку, знову породжує танцювальний зміст. Такий симбіоз танцю і драми Курт Йосс називає «Tanztheater» («танцтеатр»), вводячи у користування мистецькою спільнотою новий термін, що пізніше став назвою особливого сценічного жанру. Виникнення цього жанру значною мірою завдячує теоретичній, педагогічній та постановчій діяльності К.Йосса.

Новаторство Йосса також виявилось у зверненні до нових для балетного театру тем. Перед усім, мова йде про найвідомішу і найвизначнішу постановку Курта Йосса балет «Зелений стіл» («Der Grune Tisch»), який і досі зберігається в репертуарі бгатьох балетних труп світу (Сіті Центр Джофрі балле, Опера Ліону, Нідерландський Театр Танцю, Баварська Державна Опера, Чілійський національний балет, Опера Ессена та ін.). Вперше він був представлений на фестивалі-конкурсі європейських хореографів у Парижі, в Театрі Єлісеських полів 3 липня 1932 р., здобувши там I премію. Лібрето балету створене самим балетмейстером, оформив спектакль художник Х. Хекрот, музика Ф. Коена.

«Зелений стіл» - перший балет на політичну та антивійськову тематику. Це гротесковотрагічна притча про війну взагалі, війну - зловісне лихо, війну - жорстоку машину. Спектакль уособлює епоху, за якої він був створений. Свропа ще не забула Першу світову війну і уже стоїть на порозі Другої світової. Вічні теми війни і смерті, що супроводжують людство на протязі всієї історії та багатократно відображаються в мистецтві, вперше втілені засобами хореографії.

Наскрізної сюжетної лінії спектакль не має. Загальний зміст балету складається із окремих сцен, епізодів, замальовок. Побудований подібно до німого кіно, «Весь балет - свого роду плакат, ряд енергійних видовищних картин, що малюють жах смерті, спустошення.». [1, 319] Подібність до німого кінематографу, виражена у композиційній побудові, підсилюється музичним супроводом. Музику балету «Зелений стіл» Фріц Коен створював у безпосередньому контакті з балетмейстером. Іронічний фортепіанній фокстрот у стилі тогочасних шлягерів, наче тапер, супроводжує фантасмагоричні картини вистави.

Дія розпочинається і закінчується картиною засідання Ліги Націй. За зеленим столом, що символізує міжнародні перемовини, дипломати у офіційних чорних костюмах і масках з потворними гримасами вирішують справи миру. На зеленому тлі сукна чітко виділяються їхні руки у білих рукавичках, руки що залишаться «чистими» не зважаючи на будь-які наслідки їхніх дій. Глобальні події вистави представляються результатом діяльності купки людей, наділених владою і байдужих до наслідків власних вчинків.

Сцени, що розгортаються поміж двома зображеннями зеленого столу, які відкривають та завершують виставу, варіюють тему війни у різних іiі проявах. Сюжетні мотиви представляють проводи на війну, загибель у бою, трагічне очікування звістки 3 фронту, горе втрати близьких, наживу, наругу, розпусту... і над усім цим коловоротом подій владарює Смерть, символічний образ війни, що підкорює собі долі людей, не залишаючи їм права вибору, позбавляючи власної волі. Людина-маріонетка рухається, діє, керована Смертю, навіть не намагається протистояти іiі волі, визнаючи марність таких спроб. Тема людської покірності, пасивності - інша тема, що проходить через усі епізоди балету та усі його персонажі, які підкорюються повинності перед Смертю, обов'язку продовжувати безглузді вбивства, невідомо ким і коли розпочаті.

Дія вистави представляється поза часом, поза конкретною країною, поза конкретною особою. Всі персонажі і події балету максимально типізовані, вирішені різкими локальними красками.

3 сьогоднішніх позицій хореографічного мистецтва вистава видається, можливо, недостатньо динамічною та малонасиченою лексично. Режисерські ж принципи вирішення балетного спектаклю, конкретна символічність пластичних засобів, локанічність, органічність і цілісність вистави можуть слугувати зразком для сучасних постановників. Актуальною залишається й ідейно-тематична спрямованість балету «Зелений стіл».

31933 р. Йосс зазнає утисків збоку фашистської влади, що вимагала від балетмейстера звільнити його чисельних співробітників єврейського походження. 1934 р. Курт Йосс разом зі своєю трупою емігрує до Англії у місто Далінгтон, де також засновує хореографічну школу. У вимушеній еміграції балетмейстер продовжує постановчу та гастрольну діяльність. Виступи «Балле Йосс» 
мають великий успіх в країнах Америки. У 1947-1948 р., після розпаду власної трупи, митець працює для Національного балету Чілі.

Значним внеском у справу створення теорії сучасної хореографії стала співпраця з Р. Фон Лабаном та А. Кунстом у розробці системи запису рухів «Кінетографія», що отримала світову відомість під назвою «Лабанотація». Власні ж теоретичні споглядання К. Йосса отримали детальну розробку у системі «Еукінетика».

1949 р. митець повертається до Німеччини, щоб знову очолити школу «Фолькванг» та «Фолькванг-балет». Протягом наступних тридцяти років балетмейстер створює десятки постановок у різних театрах Німеччини та інших країн Європи. Та все ж, вершиною його творчості залишається «Зелений стіл». Помирає Курт Йосс 22.05.1979 року, ставши жертвою нещасного випадку.

Наприкінці зазначимо, що хореографічна школа, заснована Йоссом у Ессені та керована ним довгі роки, діє і по сьогодні, підготувавши за час свого існування не одне покоління виконавців та хореографів. Знаменита Folkwangschule стала «справжнім розплідником хореографів» [5, 51] найвидатнішими з яких $є$ всесвітньо відомі Піна Бауш і Сюзан Лінке.

Висновки. Підводячи підсумок дослідження, конкретизуємо напрями діяльності К. Йосса, за якими було здійснено значні новації та здобутки:

- практичний: заснування шкіл та викладацька діяльність, піднесення сучасного танцю на новий технічний рівень, започаткування нового сценічного жанру «танцтеатр», розширення тематики балетного репертуару, значний постановчий доробок;

- методичний: удосконалення системи викладання модерн-танцю;

- методологічний: запропонування нового методу творення хореографічної лексики засобом синтезу модерного та класичного танцю і не балетної пантоміми;

- теоретичний: обгрунтування та введення у науковий обіг терміну «танцтеатр», розробка системи «Еукінетика», співавторство у створенні «Кінетографії».

Таким чином, різнобічна діяльність Курта Йосса охопила різні сфери сучасної хореографії, справивши значний вплив на розвиток танцювального мистецтва багатьох країн. Збагачення нового танцю театральними засобами виразності, розширення жанрового та тематичного різноманіття вистав, виховання якісно нових танцівників, розвиток техніки та лексики сучасної хореографії, теорії хореографії - сукупність цих надбань дали змогу зробити ривок, що підніс сучасну хореографію від аматорських експериментів до рівня професійного мистецтва.

Процес синтезу танцю модерн 3 класичним танцем, започаткований К.Йоссом та іншими хореографами і викладачами у першій половині XX ст., продовжується і понині та може стати темою майбутніх наукових досліджень.

\section{Jimepamypa}

1. Демидов А. Золотой век Юрия Григоровича / Александр Демидов; редактор-составитель А. Г. Колесников. - М.: Алгоритм, Эксмо, 2007. -400 с.

2. Чепалов О. Хореографічний театр Західної Європи XX ст.: монографія / Олександр Іванович Чепалов; Харк. держ. акад. культури. - Х.: ХДАК, 2007. - 344 с.

3. Шариков Д. І. Класифікація сучасної хореографії.: монографія / Денис Ігорович Шариков; Видавець Вадим Карпенко. - К.:Видавець Карпенко В.М., 2008. - 168c.

4. 100 балетных либретто. Издание 2-е. / Ред. Л. А. Энтелис. - Л.: Музика, 1971. - 304 с.

5. Izrine A. La Danse dans tous ses etats / Agnes Izrine; Paris: L'arche, 2002.

6. Homans J. Apollo's angels: a history of ballet / Jennifer Homans; New York: Rendom House Trade Paperbacks, 2010. -640 p.

7. Marselle M., Ginot I. La Danse au XX-e siecle / Michel Marselle, Isabelle Ginot; Paris: BORDAS, 1995. $264 \mathrm{p}$.

8. Verriele P. Legendes de la Danse / Philippe Verriele; Paris: Editions hors collection, 2002. - 160 p.

\section{References}

1. Demidov A. (2007). Zolotoj vek Jurija Grigorovicha / Aleksandr Demidov; redaktor-sostavitel' A. G. Kolesnikov. - M.: Algoritm, Jeksmo [in Russian].

2. Chepalov O. (2007). Khoreohrafichnyi teatr Zakhidnoi Yevropy KhKh st.: monohrafiia. Oleksandr Ivanovych Chepalov; Khark. derzh. akad. kultury. [in Ukrainian].

3. 3.Sharykov D. I.(2008). Klasyfikatsiia suchasnoi khoreohrafii.: monohrafiia. Denys Ihorovych Sharykov; Vydavets Vadym Karpenko [in Ukrainian].

4. 100 baletnyh libretto. (1971). Izdanie 2-e. Red. L. A. Jentelis. - L.: Muzika [in Russian].

5. Izrine A. La Danse dans tous ses etats. Agnes Izrine; Paris: L'arche, 2002.

6. Homans J. Apollo's angels: a history of ballet. Jennifer Homans; New York: Rendom House Trade 
Paperbacks, 2010. - 640 p.

7. Marselle M., Ginot I. La Danse au XX-e siecle. Michel Marselle, Isabelle Ginot; Paris: BORDAS, 1995. $264 \mathrm{p}$.

8. Verriele P. Legendes de la Danse. Philippe Verriele; Paris: Editions hors collection, 2002. - 160 p.

Стаття надійшла до редакиії 09.12.2018 p. 